\title{
Nonlinear static analysis of a pile-supported wharf
}

\section{Análise estática não-linear de um cais sobre estacas}
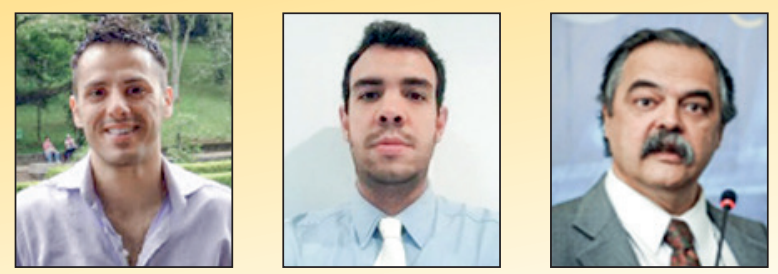

E. ZACCHEI enricozacchei@usal.es https://orcid.org/0000-0003-2537-0860

P. H. C. LYRA pedro.lyra@maua.br https://orcid.org/0000-0001-5220-7343

F. R. STUCCHI fernando.stucchi@egtengenharia.com.br https://orcid.org/0000-0003-4149-0985

\begin{abstract}
The aim of this paper is to carry out a nonlinear static analysis using a case study of a pile-supported wharf in a new oil tankers port. The seismic activity in this area is very intense with the peak ground acceleration of $0.55 \mathrm{~g}$; for this reason, it is very important to analyse the structural behaviour of the nonlinear situation. The analysis of the wharf, modelled in 3D by finite element method, serves to calculate the structure vibration periods (the structure's first period is $1.68 \mathrm{~s}$ ) and the capacity curve. The design of the structure follows traditional criteria by international guidelines, and its procedure is in accordance to classic theoretical methods and codes. For the selection of adequate characteristic earthquake input for the pushover analysis European and Venezuelan codes have been used. Besides being important to study the seismic influence on the body of the wharf and on critical elements, as well as and the interaction fluid-structure-soil, it is also important to analyse the consequences of structure failure and to estimate the maximum allowed displacement. The results show that the ultimate displacement is $18,81 \mathrm{~cm}$. A port is an extremely strategic work, which needs to be carefully designed to avoid environmental damage and maintain human safety.
\end{abstract}

Keywords: nonlinear static analysis, pushover analysis, pile-supported wharf, earthquake engineering.

\section{Resumo}

O objetivo deste artigo é desenvolver uma análise estática não-linear através de um estudo de caso de um cais sobre estacas situado em uma nova área portuária para petroleiras. A atividade sísmica da área é muito intensa com uma aceleração máxima do solo de $0.55 \mathrm{~g}$. Por esta razão, é muito importante analisar o comportamento estrutural na situação não-linear. A análise do cais, modelada em 3D pelo método dos elementos finitos, é usada para calcular os períodos de vibrações da estrutura (o primeiro período da estrutura é de 1.68 s) e a sua curva de capacidade. O projeto da estrutura segue critérios tradicionais preconizado pôr normas internacionais e o seu procedimento está de acordo com os métodos clássicos e as normas. Foram utilizadas as normas europeia e venezuelana para obter a característica adequada do terremoto para ser utilizada na análise de pushover. Além de ser importante estudar a influência sísmica da estrutura do cais e dos seus elementos críticos, bem como a interação fluido-estrutura-solo, também é importante analisar as consequências de falha estrutural e estimar o deslocamento máximo permitido. Os resultados mostram que o deslocamento final é de $18.81 \mathrm{~cm}$. Um porto para petroleiras é uma obra extremamente estratégica, que precisa ser cuidadosamente projetada para evitar danos ambientais e para manter a segurança humana.

Palavras-chave: análise estática não-linear, análise pushover, cais sobre estacas, engenharia sísmica. 


\section{Introduction}

The uncertain nature of the hazards which can be manmade or natural along with the complex dynamics of infrastructure systems impose significant challenges in decision making regarding allocation of investments. These are related to two aspects: identifying potential risks to life safety, which is typically the focus of the seismic design of the geo-structures (e.g. the bridges, tunnels, wharf structures and various air-transportation structures), and estimating costs. These two aspects, mostly uncertain, are added to other ones as the seismic hazard, the material's nonlinear behaviour, the damage and the structural response [23]. Here the nonlinear static analysis, which is commonly known as "pushover analysis", has been defined.

The pushover analysis is used for different methodologies and different types of structures, as for the inelastic dynamic analysis for shear buildings [12,28], the spatial reinforced concrete studying the effect of the infills on failure pattern of the reinforced concrete frames [19], the reinforced concrete by using a fibre model [20], the estimation of the yielding and the ultimate displacement to define the level of damage for dams [17], the energy-based adaptive pushover analysis for buildings through a series of nonlinear analysis under strong ground motions [22], the bridges with elevated pile foundation system by dynamic pushover analysis [24], and the pile-supported wharves [23].

The cited cases rely on advanced methods of pushover analyses. In general, pushover analysis is used where a structure is subjected to gravity loading and a monotonic displacement-controlled lateral load pattern, which continuously increases through elastic and inelastic behaviour until an ultimate condition is reached. Therefore, the choice of a reliable method is important. The conventional pushover analysis by using the response spectrum is often an attractive choice for its simplicity and ability to identify component and system-level deformation requirements with comparable accuracy to the dynamic analysis. Some problems like defining ductility, base shear and formation of plastic hinges lead to the choice by engineers of a more reassuring and already used method.

This paper describes the nonlinear (inelastic behaviour) static analysis through modelling the pile-supported wharf of a new oil tankers port. It will be introduced geotechnical aspects and the seismic context to define the area of study. The seismic activity in this area is very high, therefore it is important to carry out a performance verification of this new structure and to study its vulnerability. The comparison between the Venezuelan code [7] and Eurocode [6] has been made, and it will be defined the technical data of the structure.

The pushover procedure will be shown step by step. The pushover curve analysis evaluates the structure capacity whereas the elastic spectrum curve evaluates its demand; the intersection between both curves is the maximum response in terms of displacements. Points in the pushover curve represent the plastic hinge formations. To consider the non-linear inelastic behaviour of the structure, the viscous damping ratio are applied to the elastic response spectrum, which becomes to an inelastic response spectrum [1] The nonlinear analysis is needed to identify the sources of energy dissipation and to quantify the energy absorption capacity.

Push-over analysis monitors the progressive stiffness degradation of structure as it is loaded into the post-elastic range of behaviour [21]. This analysis account for material inelasticity, type of member (beam, piles, connections), geometric nonlinearity and the redistribution of internal forces [25].

The wharf will be modelled in three dimensions by using Finite Element Method (FEM), software [16], and the results will be presented. The modal analysis to calculate the vibration periods and modal participating mass have been carry out to assure reliable results, it is recommended that an effective modal mass of at least $90 \%$ of the total mass of the structure is considered in the analysis. The analysis and the design of the structure have been carried out by using the latest construction techniques, and the verifications and calculations have been carried out by modern codes and criteria. This paper originates from technical work and it intends to encourage a closer connection between researchers and practical structural engineering professionals to resolve potential controversial issues.

\section{Case study}

The case study is a pile-supported wharf in ports. In this section, geotechnical and seismic aspects will be described because it is well known that earthquakes affect many elements of the buildings in the region near the port.

\subsection{Geotechnical aspects}

The region studied has high seismicity with an important liquefaction potential $[9,18]$. Liquefaction is the process by which the sediments immersed suffer a loss of resistance and stop behaving as a solid to become a viscous liquid. Sediment types more susceptible to liquefaction are sand and silt. The liquefaction depends primarily on intensity of earthquake, Peak Ground Acceleration (PGA), magnitude, soil density, presence of silt and limitation of the drainage. If the liquefaction occurs the effects can be: (i) lateral displacements of blocks of land. These lateral displacements occur with low slopes and move to sea-side; (ii) ground displacement which usually cause internal ruptures (fissures, cracks and scarps) that can damage the foundations; (iii) vertical movements which can be developed as a result of the readjustment of liquefied soil. These displacements can be rigid or differential. To prevent these problems important treatments have been adopted, for example: soil changing, drain putting, and mix of the cement and grouting.

\subsection{Seismic context}

For the evaluation of the elastic response spectrum, the Venezuelan code Covenin [7] and the Eurocode [6] have been used.

The Venezuelan code Covenin is used with the following input data: $\mathrm{A}_{0}=0.4, \alpha=1.3$ and spectrum form S2. $\mathrm{A}_{0}$, $\alpha$ and $\mathrm{S} 2$ correspond respectively to: horizontal acceleration coefficient for high seismic risk (for zone 7), importance factor which depends on the importance of building classes, and the soil type. In Figure 1 it is possible to see the curve with the corresponding structural damping. The elastic design spectrum with a $5 \%$ damping $(\xi)$ is used generally for reinforced concrete.

For the horizontal elastic spectrum by Eurocode the date used are: $\mathrm{a}_{\mathrm{g}}=0.48 \mathrm{~g}$ (design ground acceleration. This parameter has been 


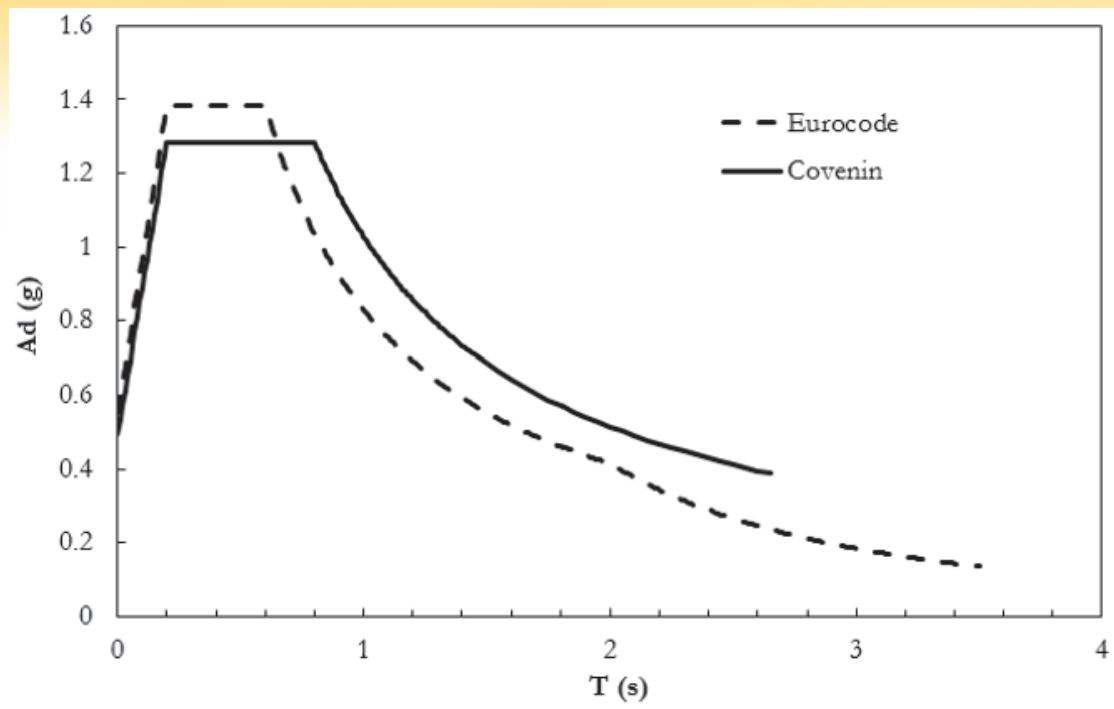

Figure 1

Design response spectra with return period TR of 475 years and $\xi=5 \%$

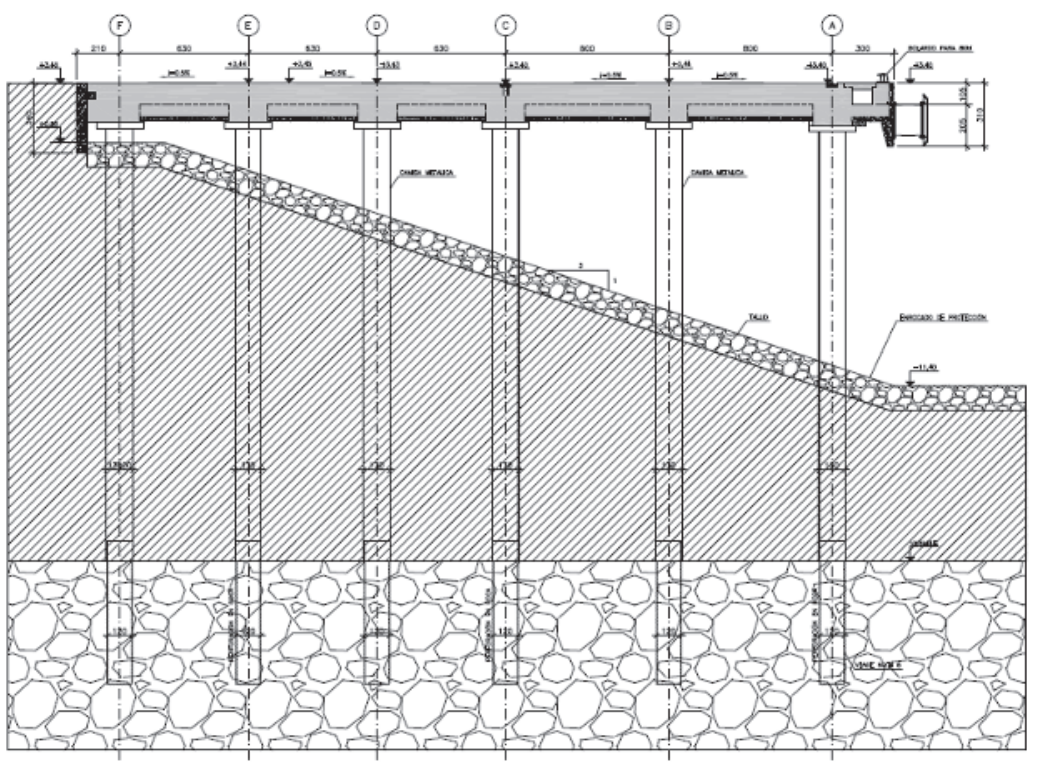

\section{Figure 2}

Cross section of the pile-supported wharf (data are shown in Table 1)

calculated with a specific study due to the importance of the structure and the high seismicity), $\mathrm{S}=1.15$ (soil factor), $\mathrm{T}_{\mathrm{B}}=0.20 \mathrm{~s}$ (lower limit of the period of the constant spectral acceleration branch where the spectral velocity is linear), $T_{C}=0.60 \mathrm{~s}$ (upper limit of the period of the constant spectral acceleration branch) and $T_{D}=2.00$ $\mathrm{s}$ (value defining of the constant displacement response range of

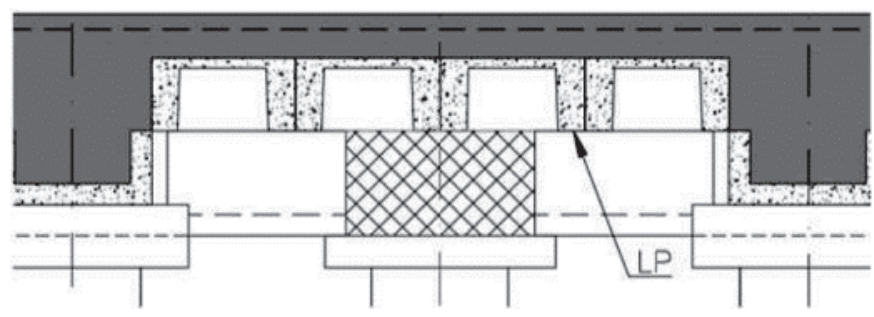

Figure 3

Concrete slab (LP: prefabricated slab) the spectrum). The PGA is $0.55 \mathrm{~g}$ ( $55 \%$ of gravity).

For frequencies lower than $1.56 \mathrm{~Hz}(\mathrm{~T}>0.64 \mathrm{~s})$, in Figure 1 it is possible to notice that the code Covenin spectrum is higher therefore it is more conservative. This would not be very relevant because, for flexible structures ( $T>1.50 \mathrm{~s}$ ), the accelerations are not transmitted totally to the structure.

In Figure 1 it is possible to see that the spectral shape of code Covenin has only three branches, instead the Eurocode has four ones. In the Eurocode, the fact of putting another branch is an adjustment made not to overestimate structures with period between $0.6-2.0 \mathrm{~s}$. The Covenin maintaining three branches is consistent with the tripartite format of spectral velocity [10].

\subsection{Pile-supported wharf}

The structure studied has an area of $6520 \mathrm{~m}^{2}$. The length of the wharf in the transversal direction is $40 \mathrm{~m}$ and in the longitudinal direction (parallel to the sea) is $163 \mathrm{~m}$ (see Figure 2 by 
software [29]). The deck of the wharf is made of reinforced transversal beams with height of $1.95 \mathrm{~m}$ and concrete slab with average thickness of $0.85 \mathrm{~m}$, as shown in Figure 3.

The wharf level is $3.40 \mathrm{~m}$ above the Mean Sea Level (MSL), with a minimum and maximum flood respectively of $-0.40 \mathrm{~m}$ and $+0.875 \mathrm{~m}$

The wharf is supported by six piles. The beams supported by the piles have a metal jacket to prevent the deterioration due to corrosion of reinforcement, weathering and chemical attacks. The metal jacket tends to isolate the concrete from chemical constituents present in the environment, to isolate against freezing and to keep the reinforcing free of oxygen. Table 1 shows the data of the structure.

The cross sections have the same cross-sectional geometry for all piles and they include the longitudinal reinforcement bars, metal jacket, and confined and unconfined concrete material. In Figure

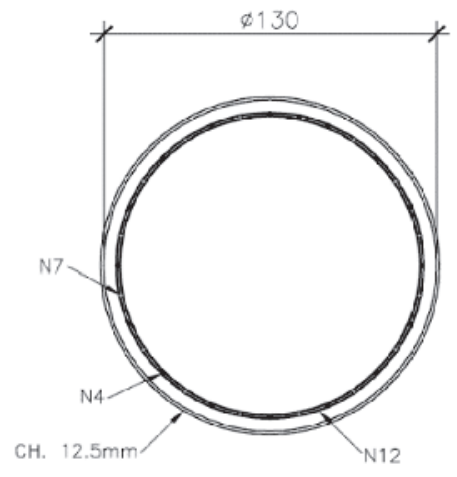

a

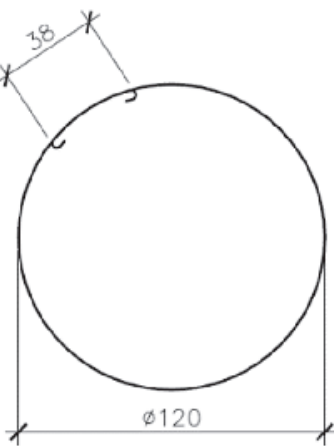

N12-52 $\varnothing 12.5 \quad \mathrm{C}=438$

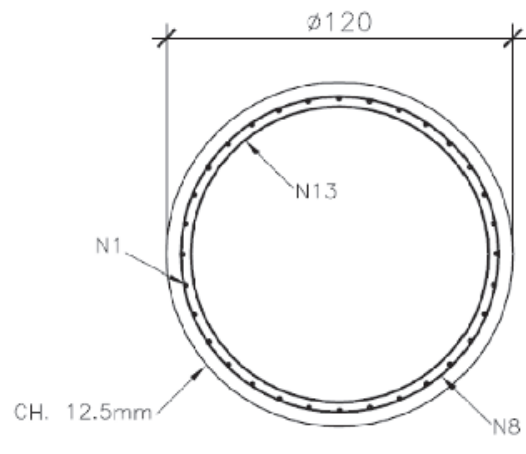

b
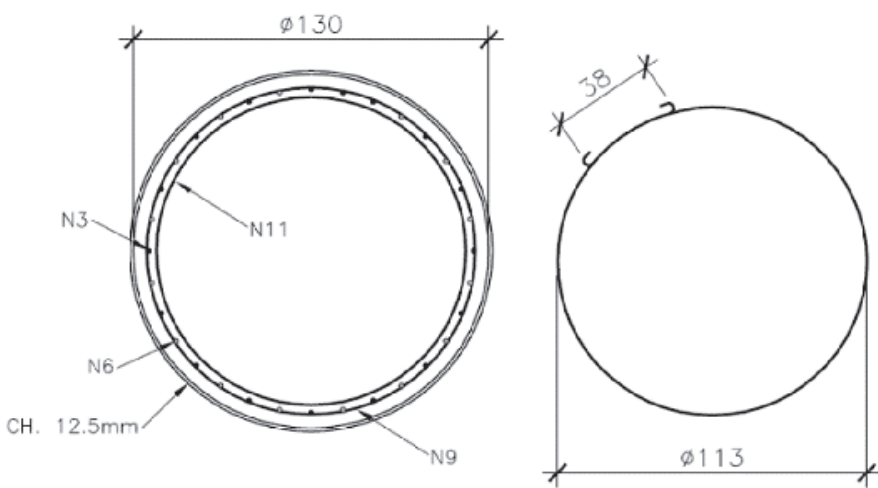

$\mathrm{N} 11-12 \varnothing 16 \mathrm{C}=425$

C

\section{Figure 4}

Cross section at top (a), middle (b) and bottom (c) of the piles (the dimension is in $\mathrm{mm}$ )

(C: reinforcing length in $\mathrm{cm}$ )

\section{Table 1}

Data summary of the pile-supported wharf

\begin{tabular}{|c|c|c|c|}
\hline Description for the pile & Value & Description for the wharf & Value \\
\hline Pile length $(\mathrm{m})$ & 30.0 & Number of piles & 6.0 \\
\hline Pile external diameter $\phi(\mathrm{mm})$ & $120 / 130$ & Wharf longitudinal length B (m) & 40.0 \\
\hline Pile internal diameter $\phi(\mathrm{mm})$ & $103 / 113 / 120$ & Wharf transversal length $\mathrm{LL}(\mathrm{m})$ & 163.0* \\
\hline Pile thickness $\mathrm{CH}$. (mm) & 12.5 & Deck area $\left(m^{2}\right)$ & $163.0 \times 40.0=6520.0$ \\
\hline $\begin{array}{l}\text { Pile reinforcing diameter: N1 }(32)^{* *}, \mathrm{~N} 3(16) \text {, } \\
\quad \text { N4 (16), N6 (16), N7 (16), N8 (32) (mm) }\end{array}$ & 32.0 & Wharf level (m) & $3.4-0.40,3.4+0.875$ \\
\hline Pile reinforcing diameter: N9 (1), N12 (52) (mm) & 12.5 & Deck thickness $(m)$ & 1.05 \\
\hline Pile reinforcing diameter: $\mathrm{N} 11$ (12), N13 (7) (mm) & 16.0 & Deck transversal slope (\%) & 0.5 \\
\hline Jacket external diameter D.E $\phi(\mathrm{mm})$ & $130 / 132.5$ & Soil slope & $3: 1$ \\
\hline Jacket internal diameter D.I (mm) & 127.5 & - & - \\
\hline Jacket thickness CH. (mm) & $12.5 / 25$ & - & - \\
\hline
\end{tabular}

${ }^{*}$ The wharf transversal length is defined as $(2 \times 8.0)+(3 \times 6.3)+3.0+2.1=163.0 \mathrm{~m}$

**The value in the brackets indicates the quantity of the reinforcing. 


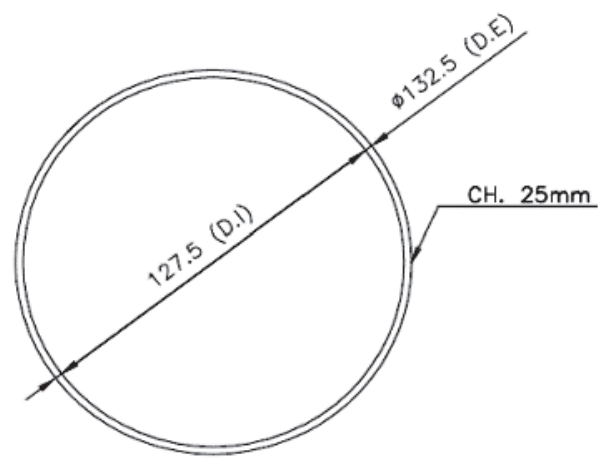

a

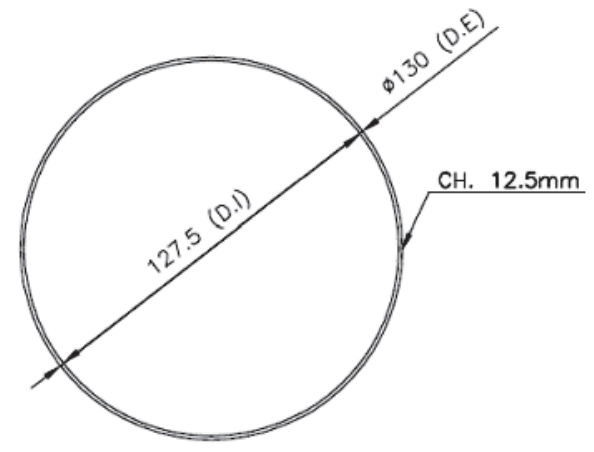

b

\section{Figure 5}

Cross section of the metal jacket at top ( $a$ ), middle (b) and bottom (a) of the piles (the dimension is in $\mathrm{mm}$ )

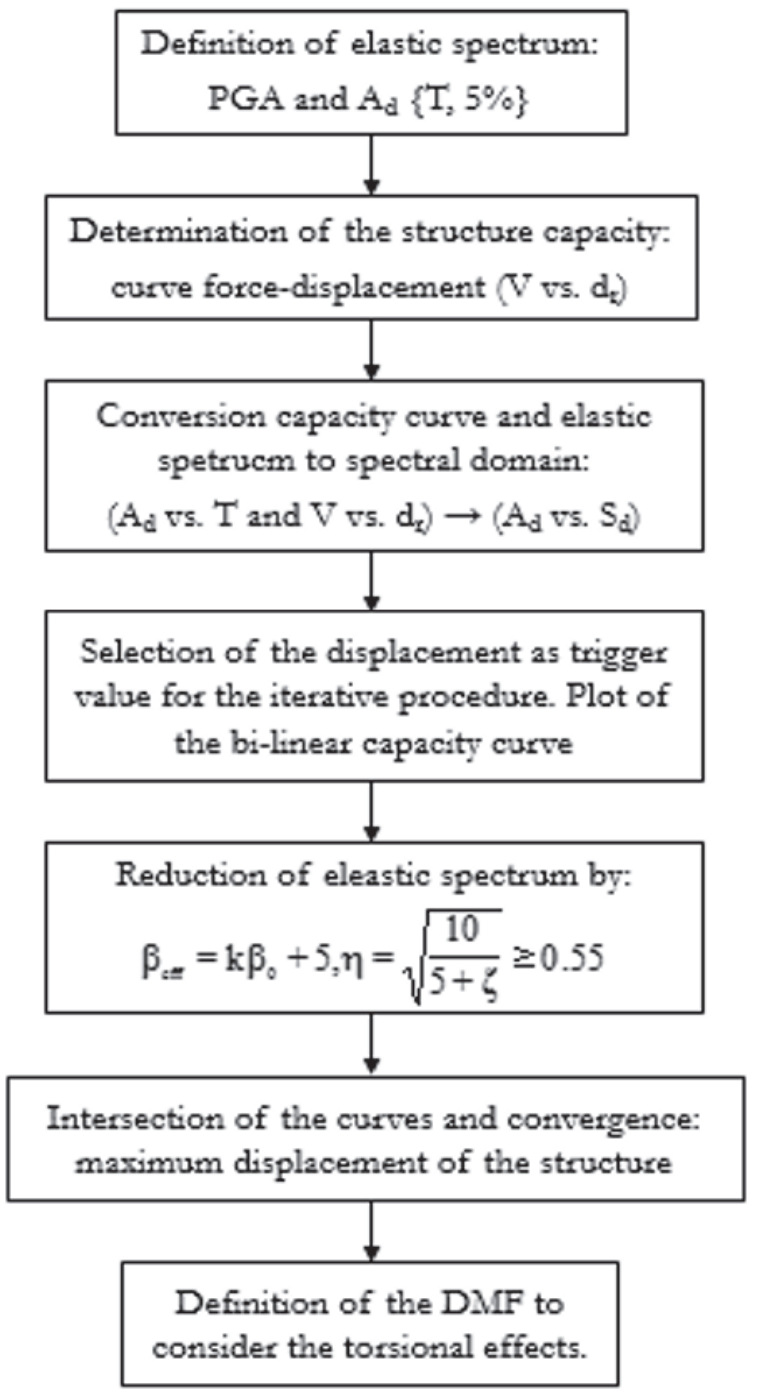

Figure 6

Flow chart of the procedure
4, the cross sections of the piles by software [29] are represented by (a), (b) and (c) from top to bottom of the piles. Figure 5 shows the cross section of the metal jacket of the piles by software [29]. The reinforced concrete of the piles plus the great thickness of the reinforced deck provides a high increase of the rigidity in the horizontal plane.

\section{Pushover analysis step by step}

The pushover analysis is a Nonlinear Static Procedure (NSP) usually used for nonlinear issues. In this analysis, the method used is the Capacity Spectrum Method (CSM) that is a performance-based seismic analysis that relates the capacity with the demand of the structure. The CSM uses Response Spectrum Analysis (RSA) and it is computationally easy for routine application in structural engineering practice. The iterative procedure of this method was given by [3]. Figure 6 shows the flow chart of the procedure.

\subsection{Seismic demand}

The CSM is based on finding a target point on the capacity spectrum - that also lies on the appropriate demand response spectrum - reduced for nonlinear effects. The spectral reduction factor is the viscous damping ratio, which affects the seismic demand displacement and the hysteresis loop. The elastic response spectrum, in terms of acceleration $A_{d}$ for $5 \%$ damping and return period $T_{R}$ of 475 years, is shown in Figure 1.

\subsection{Determination of the structure capacity}

It is convenient to draw the force-displacement curve by tracking the base shear $V$ and the roof displacement $d_{r}$. The force-displacement curve $\left(V\right.$ vs. $\left.d_{r}\right)$ is representative of the structure capacity by the pushover analysis.

The centre of the mass of the structure may be equal to the control displacement (control point) during the analysis.

In the model, it is necessary to apply the lateral forces to the structure in proportion to the mode shape. It is also important to apply the uniform lateral forces to consider the effects of other mode shapes. 
The capacity curve is generally constructed by using the first mode as it is the predominant mode of the structure. In this case the structure is flexible, therefore in the analysis the higher mode effects [26] should be considered. Neglecting them in the analysis the shear forces will be significantly underestimated [27].

This analysis is carried out under constant gravity loads and monotonically increasing horizontal loads. The forces considering the combination of the vertical load and lateral load must be calculated. The lateral loads are defined by the inertia forces, which are distributed for each mode and are applied to the deck of the structure where the mass is concentrated.

For the vertical loads in the elements, zero initial condition stiffness is used. For the horizontal loads, no zero-initial condition is used this means that the nonlinear deformations are carried forward from a previous step to the end.

The more new increments of lateral loads are applied the more additional pushover curves are created. The creation of more pushover curves is important to define the accuracy of degradation points as each pushover step involves the formation of new plastic hinges.

\subsection{Conversion to spectral domain}

In this step, the capacity pushover curve and the demand curve are converted to spectral domain. That is, the elastic response spectrum and the capacity curve are transformed in ADRS (Acceleration-Displacement Response Spectra) domain. The equations to transform the response spectrum follow below:

$A_{d}=\frac{V / W}{\alpha_{1}}$

$S_{d}=\frac{d_{r}}{P F_{1} \phi_{r, 1}}$

where $S_{d}$ is the spectral displacement, $W$ is the dead weight plus live loads, and $\phi_{r, 1}$ is the amplitude of mode one at level deck. The modal participation factor and the modal mass coefficient for the first natural mode are respectively:

$\mathrm{PF}_{1}=\frac{\sum_{i=1}^{N} \frac{w_{i} \phi_{i 1}}{g}}{\sum_{i=1}^{N} \frac{w_{i} \phi_{i 1}^{2}}{g}}$

$\alpha_{1}=\frac{\left(\sum_{i=1}^{N} \frac{w_{i} \phi_{i 1}}{g}\right)^{2}}{\left(\sum_{i=1}^{N} \frac{w_{i}}{g}\right)\left(\sum_{i=1}^{N} \frac{w_{i} \phi_{i 1}^{2}}{g}\right)}$

where $\mathrm{N}$ is the level which is the uppermost in the main portion of the structure, $w_{i} / g$ is the mass assigned to level $i$, and $\phi_{i, 1}$ is the amplitude of mode one at level i.

Every point on the response spectrum is associated with a unique $A_{d}, S_{d}$ and spectral velocity $S_{v}$. An interesting use of these curves is to estimate dynamic amplification factor by dividing spectral values by ground motion values [10]. The equations to transform the period $T$ from the standard format $\left(A_{d} v s . T\right)$ to spectral displacement $\left(A_{d}\right.$ vs. $\left.S_{d}\right)$ for each point $i$, is:

$S_{d i}=\frac{T_{i}^{2}}{4 \pi^{2}} S_{a i} g$
On the response spectrum, every point is also associated with a unique structural period, which, in the ADRS domain, is defined by the line of constant period radiate from the origin. When a line with a greater slope (i.e. lower period) changes to a line with a lower slope (i.e. greater period) the structure undergoes inelastic displacement as the period grows.

\subsection{Selection of the displacement}

To establish the target, point the methodology called "equal displacement approximation" is used. This methodology assumes that the inelastic spectral displacement is the same as the one which would occur if the structure remained perfectly elastic. The elastic displacement is calculated extending initial stiffness line up to intersect elastic response spectrum. This displacement acts as a trigger value to carry out the iterative procedure. A possible iterative procedure is represented in section B.5 in Eurocode [6]. Displacements refer to the single-degree-of-freedom system.

\subsection{Plot of the bi-linear capacity curve}

The plot of the bi-linear curve is needed to estimate the viscous damping ratio and the appropriate reduction of the spectral demand. The approximation of the capacity spectral curve is in accordance with the criteria of equal elastic energy (or work) [26]. To define the bi-linear curve it is necessary to know two points: the first point represents the yield displacement and the second represents the estimation to define the reduced spectrum. Besides that, it is necessary to define the elastic and post-elastic stiffness.

\subsection{Reduction of the spectral demand}

The effective viscous damping can be considered as a combination of the viscous damping (i.e. internal friction in the material) and the hysteretic damping. The effective viscous damping is defined by:

$\beta_{\text {eff }}=\kappa \beta_{o}+5=\frac{63.7 \kappa\left(a_{y} d_{p i}-d_{y} a_{p i}\right)}{a_{p i} d_{p i}}$

where $d_{y}$ and $a_{y}$ are the yield point coordinates, $d_{p i}$ and $a_{p i}$ are the point coordinates, which are estimated to carry out the reduced spectral demand. The hysteretic damping $\beta_{0}$ depends on energy dissipated by strains (i.e. during the inelastic phase the energy will be absorbed by hysteretic damping). The factor $\mathrm{k}$ depends on structural behaviour, quality of element materials and duration shaking. If the factor $k$ increases, the effective viscous damping increases and the capacity of the structure to dissipate energy is greater. With a lower $\mathrm{k}$ there are strong degraded hysteretic cycles. The hysteretic behaviour is ideal when it is stable and has large hysteretic cycles.

$\beta_{\text {eff }}$ defined by (6) is used to calculate the spectral reduction factor $\eta$, which multiplied by the elastic spectrum reduces the spectrum itself. According to the Eurocode [6], $\eta$ is assumed:

$\eta=\sqrt{\frac{10}{(5+\xi)}} \geq 0.55$

In this analysis $\xi$ becomes $\beta_{\text {eff }}=10 \%, k=0.5, \beta_{0}=10 \%$ and $\eta=0.816$.

The choice of reducing response spectrum is often complex (even 
in the codes it is "guessed"), therefore it should be based on observations of existing structures and laboratory studies.

\subsection{Intersection of the curves and convergence}

When the displacement, at the intersection of the demand spectrum and the capacity spectrum, is within $5 \%$ of the displacement of the target point, the convergence finishes. If this does not occur, the process must be repeated. The target point represents the maximum top displacement expected from the structure.

\subsection{Dynamic Magnification Factor (DMF)}

Most of the seismic lateral resistance of marginal wharves is provided by landward piles due to long embedment in soil. The seaward piles are mainly used for gravity loads and might provide about $10 \%$ of the overall seismic lateral resistance. This configuration creates eccentricity between the mass centre and the effective centre of rigidity for the wharf, which will induce torsional response in the structure under longitudinal excitation. Displacement demand of the critical piles at the end of a segment can be determined by multiplying the displacement demand calculated under pure transverse excitation by DMF, which accounts for torsional response and simultaneous longitudinal and transverse excitations, and interaction across expansion joints $[5,30]$.

\section{Analysis by FEM}

FEM has been used to model the pile-supported wharf. The masses present in the model to carry out the pushover analysis, in accordance to $[2,5,15]$, are: superstructure mass, accidental mass, a third of the mass piles and hydrodynamic mass. The masses are placed at the top of the piles.

The focus of the verification of the structure is to define the resistance capacity under a design seismic. It is admitted that the piles suffer plastic mechanisms, before the collapse, in the connection with the superstructure.

The structural analysis approach is called "displacement based design", which evaluates the structural performance in function of the displacement and rotation capacity of the piles. Thus, the analysis evaluates the formation of the plastic hinges.

To model the soil, elastic springs based on the Winkler model $[2,14]$ have been used. The piles are discretized into several segments with a length of $1.0 \mathrm{~m}$ and each node on the pile is connected to a horizontal spring
The profile of the soil at the location of pile-supported wharf consists of three layers: marine sediments of sandy soil and clay with a thickness of $15.0 \mathrm{~m}$, "coche"-formation with a thickness of $10.0 \mathrm{~m}$, and "manicuare"-formation with a thickness of $5.0 \mathrm{~m}$. The values of the elastic springs are for the three layers $4905 \mathrm{kN} / \mathrm{m}^{3}, 39240 \mathrm{kN} /$ $\mathrm{m}^{3}$ and $49050 \mathrm{kN} / \mathrm{m}^{3}$, respectively.

To consider the variation of the soil stiffness during the earthquake, two models are analyzed. The first model considers the elastic spring stiffness $\mathrm{K}$ as $\mathrm{K}^{\prime}=0.5 \mathrm{~K}$, whereas the second model considers $\mathrm{K}$ as $\mathrm{K}^{\prime}=1.5 \mathrm{~K}$.

\subsection{Modal analysis}

To carry out the modal analysis, the lumped masses were assigned on the deck of the wharf. All masses represent all the loads on the structure, except for the self-weight as the software itself considers it. Table 2 shows the first six vibration modes: period of oscillation $T_{i}$, frequency of oscillation $\mathrm{f}_{\mathrm{i}}$ and the Modal Participating Mass Ratio (MPMR) $U_{x}, U_{y}, U_{z}, R_{x}, R_{y}$ and $R_{z}$. MPMR provides a measure of how important computing the response of the structure in each of the three global directions $(x, y, z)$ is, and of how the modes are required to achieve a given level of accuracy for the analysis.

In Table 2 it is possible to notice that the structure is flexible, i.e. $\mathrm{T}_{1}>1.50 \mathrm{~s}$.

Due to structure flexibility, displacement of the centre of the mass and the centre of the stiffness, it is important to consider the torsion effects that can produce significant relative eccentricity. Fortunately, the pile-supported wharf is regular.

For the first three modes of vibration, considering each of the three directions $(x, y, z)$, the sum of the MPMR is: $U_{x}+U_{y}+U_{z}+R_{x}+R_{y}$ $+\mathrm{R}_{\mathrm{z}}=100 \%$.

It is advisable to carry out the pushover analysis along the direction where MPMR is high [11], i.e. in this analysis, $U_{x}$ for the second mode is very high $\left(U_{x}=99.77 \%\right)$, therefore the most critical pushover analysis is possible to be done in this direction.

To understand the output data of Table 2, it must be considered that the modelled structure is only one module of a whole wharf. However, the interaction with the other modules have been considered.

\subsection{Nonlinearity of the material}

Two important analyses must be carried out to consider the nonlinear behaviour: (i) assignment of the plastic hinges and (ii) definition of material properties.

\section{Table 2}

Modal analysis output

\begin{tabular}{cccccccc}
\hline $\mathbf{T}_{\mathbf{i}}(\mathbf{s})$ & $\mathbf{f}_{\mathbf{i}}(\mathbf{H z})$ & $\mathbf{U}_{\mathbf{x}}(\%)^{*}$ & $\mathbf{U}_{\mathrm{y}}(\%)^{*}$ & $\mathbf{U}_{\mathbf{z}}(\%)^{*}$ & $\mathbf{R}_{\mathrm{x}}(\%)^{* *}$ & $\mathbf{R}_{\mathrm{y}}(\%)^{* *}$ & $\mathbf{R}_{\mathbf{z}}(\%)^{* *}$ \\
\hline 1.684 & 0.594 & 0.15 & 63.51 & 0.0 & 0.0 & 0.0 & 36.33 \\
1.478 & 0.677 & 99.77 & 0.22 & 0.0 & 0.0 & 0.0 & 0.00 \\
1.239 & 0.807 & 0.07 & 36.26 & 0.0 & 0.0 & 0.0 & 63.66 \\
0.138 & 7.258 & 0.0 & 0.0 & 19.20 & 0.40 & 21.89 & 0.0 \\
0.132 & 7.574 & 0.0 & 0.0 & 48.17 & 1.26 & 27.88 & 0.0 \\
0.127 & 7.872 & 0.0 & 0.0 & 0.10 & 27.15 & 0.11 & 0.0 \\
\hline
\end{tabular}

*Modal participating mass ratio in the horizontal planes $x$ and $y$, and vertical plane $z$ (translation).

**Modal participating mass ratio in the horizontal planes $x$ and $y$, and vertical plane $z$ (rotation). 


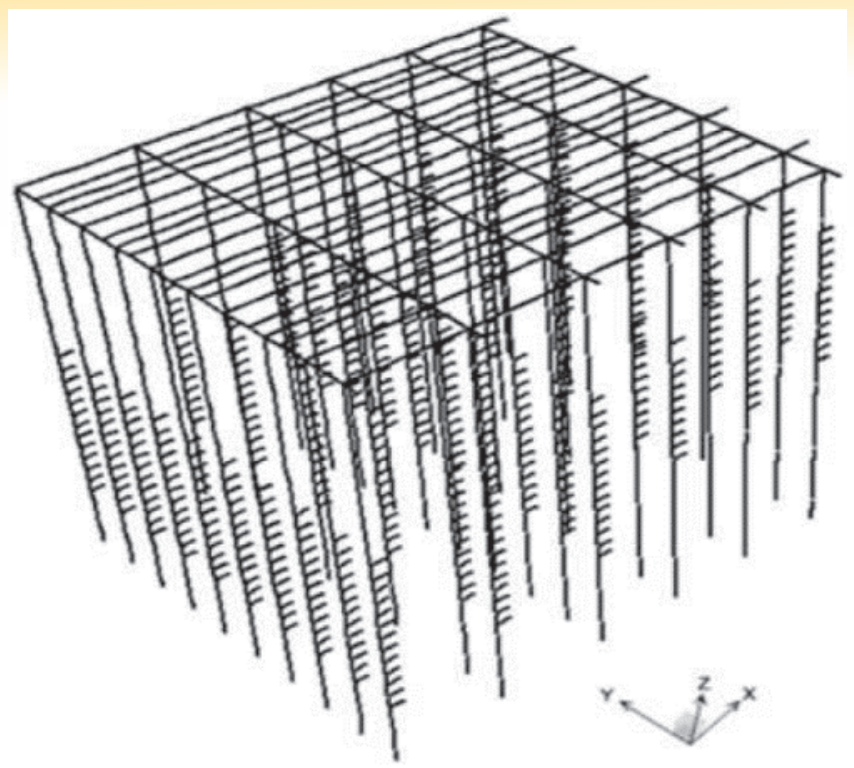

Figure 7

Pile-supported wharf model by FEM

In the model 44 lumped plastic hinges to describe the nonlinear behaviour of structural elements have been applied. Plastic hinges were put at the points where the bending moment has the maximum value. In particular, for $\mathrm{K}^{\prime}=0.5 \mathrm{~K}$ the maximum moment is $16539 \mathrm{kN}$ m whereas for $\mathrm{K}^{\prime}=1.5 \mathrm{~K}$ the maximum moment is 16438 $\mathrm{kN} \mathrm{m}$. These points correspond to the top and bottom of the piles. The plastic rotations at the connection of the piles and the wharf, and the plastic rotations in the connection of the pile with the bedrock, had been established by literature [4]. In the analysis the formation of plastic hinges begins from the top of the piles in the second row, parallel to $y$-axis, starting from the right (see Figure 7). Then the plastic hinges are extended in all the heads of the piles. Procedure steps to define the input data in the software to obtain the pushover curve are summarized below: (i) application of masses in the joints. The masses can be applied in the joint or the mass can be transformed in loads; (ii) if necessary, the stiffness reduction of the elements due to the cracks must be considered; (iii) definition of the plastic hinge sections. The geometry of the concrete, steel and metal jackets must be drawn (e.g. diameter, shape, width); (iv) definition of the constitutive law of the concrete and steel (e.g. modulus of elasticity, stress, strain); (v) assignment of the plastic hinges in the model; (vi) application of the load patterns and results of the pushover curve. Figure 8 shows the flow chart of these steps.

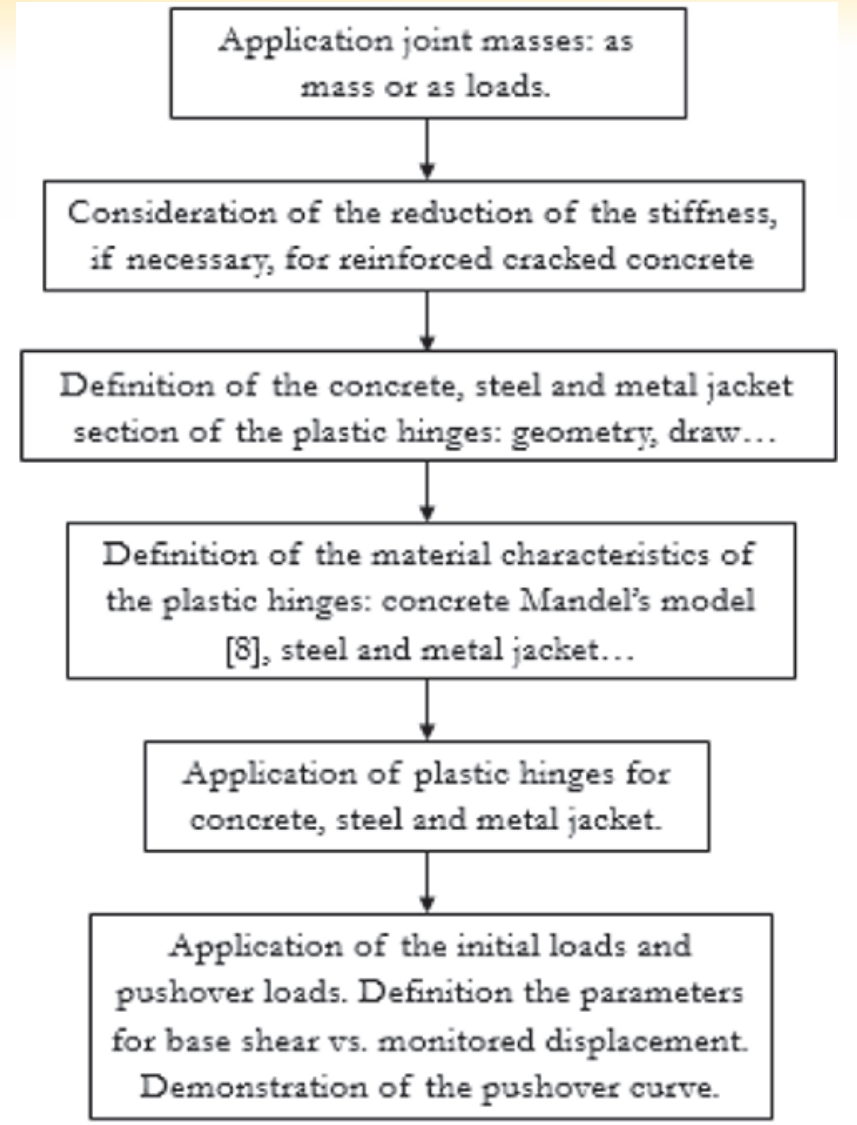

\section{Figure 8}

Pushover analysis step-by step by using software

The properties of the plastic hinges include the section reinforcement and the strength expected values of the steel and confined concrete.

The capacity of the structural element materials to resist all seismic actions must be since their properties provide a more realistic estimate for designing strength. The used stress-strain model for confined concrete, applicable to circular shaped transverse reinforcement, is the Mander's model [8]. Table 3 shows the properties of the plastic hinges.

\subsection{Pushover analysis results}

Figures 9 and 10 show the analysis results through the response spectrum and the pushover curve. It is possible to see the point

\section{Table 3}

Properties of the plastic hinges

\begin{tabular}{|c|c|c|}
\hline & \multirow{2}{*}{ Description } & \multirow{2}{*}{ Value } \\
\hline & & \\
\hline \multirow{2}{*}{ Pile concrete } & Compressive strength $\mathrm{f}_{\mathrm{ce}}(\mathrm{MPa})$ & 50.99 \\
\hline & Elastic modulus $\mathrm{E}_{\mathrm{c}}(\mathrm{GPa})$ & 29.52 \\
\hline \multirow{2}{*}{ Metal jacket } & Yield strength $\mathrm{f}_{\mathrm{ye}}(\mathrm{MPa})$ & 269.68 \\
\hline & Elastic modulus $\mathrm{E}_{\mathrm{s}}(\mathrm{GPa})$ & 205.94 \\
\hline \multirow{2}{*}{ Pile reinforcement } & Yield strength $\mathrm{f}_{\mathrm{ye}}(\mathrm{MPa})$ & 539.36 \\
\hline & Elastic modulus $\mathrm{E}_{\mathrm{s}}(\mathrm{GPa})$ & 205.94 \\
\hline \multirow{4}{*}{ Confined concrete by [8] } & Longitudinal compressive strain $\varepsilon_{\mathrm{cc}}(\%)$ & 0.56 \\
\hline & Compressive strength $\mathrm{f}_{c c}^{\prime}(\mathrm{MPa})$ & 72.92 \\
\hline & Longitudinal compressive strain $\varepsilon_{\mathrm{cu}}(\%)^{*}$ & 3.57 \\
\hline & Compressive strength $\mathrm{f}_{\mathrm{cu}}^{\prime}(\mathrm{MPa})^{*}$ & 43.81 \\
\hline
\end{tabular}

\footnotetext{
*These parameters refer to the first hoop fracture of the confined concrete pile.
} 


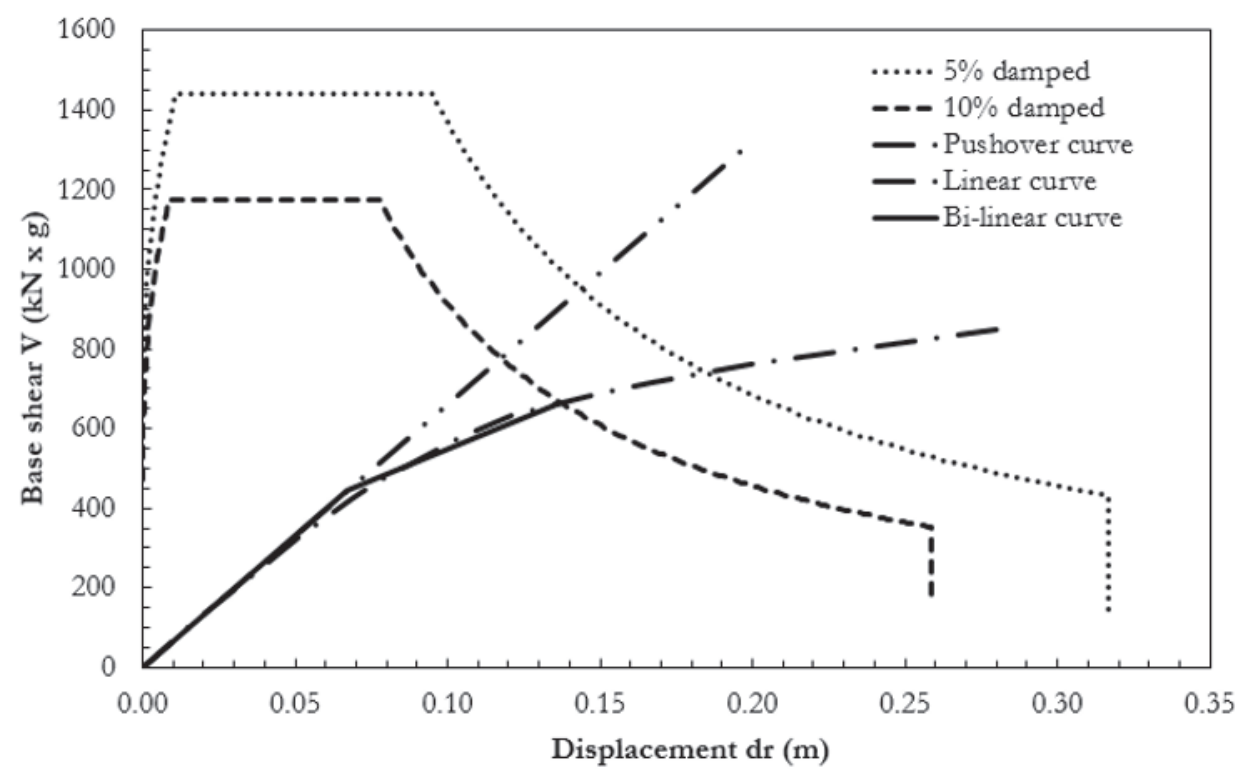

\section{Figure 9}

Response spectra, linear curve, bi-linear curve and pushover curve. The pushover analysis refers to the second mode on the $x$ direction for $\mathrm{K}^{\prime}=0.5 \mathrm{~K}$. The maximum allowed displacement is $13.74 \mathrm{~cm}$ (intersection between pushover curve and response spectrum for 10\% damped)

where the pushover curve changes inclination, which represents the first degradation of the structure (yield strength). Before, the structure remains linear-elastic with a well energy reserve capacity. The point when the pushover curve intersects the inelastic spectrum represents the maximum allowable degradation. Finally, when the pushover curve reaches the last point (ultimate strength), the structure has instability and excessive distortions, and the elements (primary and/or secondary) reach a lateral deformation level at which loss of gravity load occurs. It is possible that the ultimate strength is lower, therefore the structure will collapse beforehand.

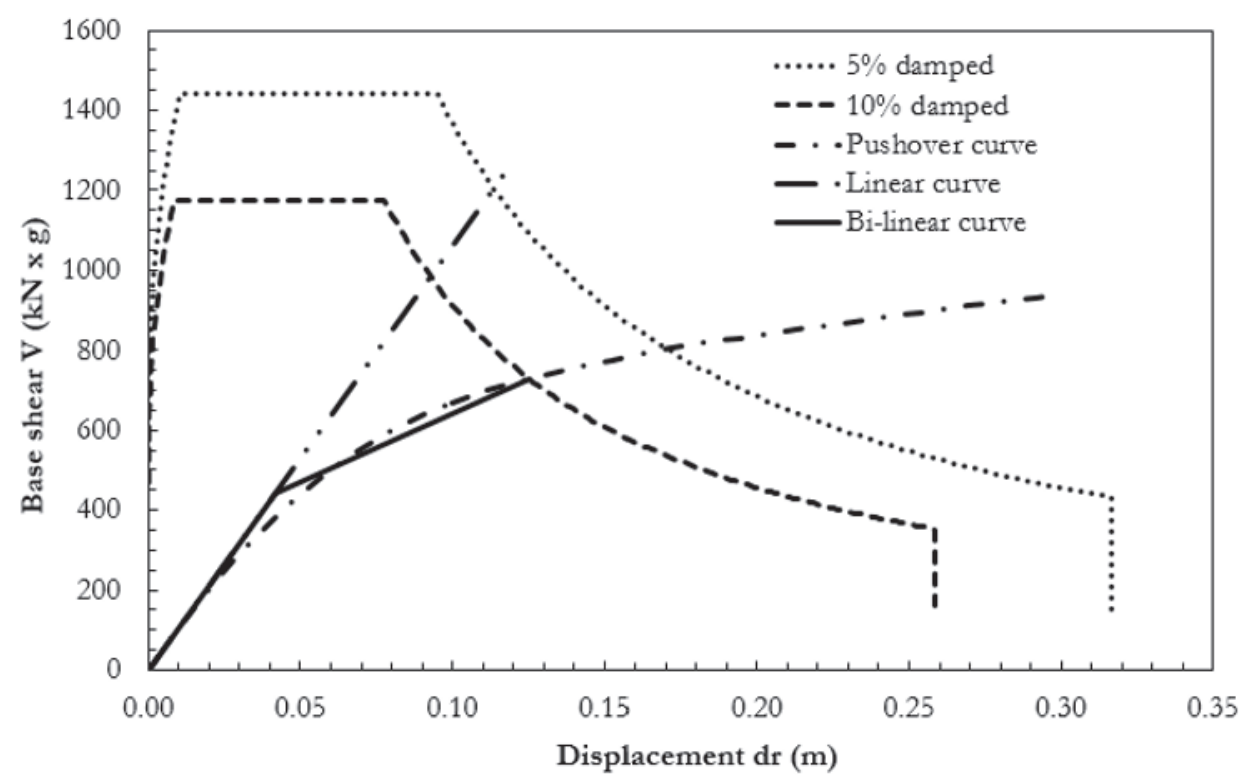

\section{Figure 10}

Response spectra, linear curve, bi-linear curve and pushover curve. The pushover analysis refers to the second mode on the $x$ direction for $\mathrm{K}^{\prime}=1.5 \mathrm{~K}$. The maximum allowed displacement is $12.54 \mathrm{~cm}$ (intersection between pushover curve and response spectrum for 10\% damped) 
Table 4

Pushover analysis results for $\mathrm{K}^{\prime}=0.5 \mathrm{~K}$

\begin{tabular}{|c|c|c|c|c|c|}
\hline & $\begin{array}{c}\text { Base shear V } \\
\text { (MN) }\end{array}$ & $\begin{array}{l}\text { Displacement } d_{r} \\
(\mathrm{~cm})\end{array}$ & $\begin{array}{l}\text { Elastic stiffness } \\
(\mathrm{kN} / \mathrm{m})\end{array}$ & $\begin{array}{l}\text { Curve area } \\
\text { (MN cm) }\end{array}$ & $\begin{array}{c}\text { PSA } / \mathrm{g}=\mathrm{V} / \mathrm{M} \\
\left(\mathrm{m} / \mathrm{s}^{2}\right)\end{array}$ \\
\hline \multirow{2}{*}{ Bi-liner curve } & 4.42 & 6.69 & 66068.76 & 14.78 & 0.33 \\
\hline & 6.63 & $13.74^{a}$ & $31347.52^{\circ}$ & 53.74 & 0.50 \\
\hline \multirow{3}{*}{ Liner curve ${ }^{b}$} & 8.00 & 11.60 & & & 0.60 \\
\hline & 9.51 & 14.40 & 66068.76 & 132.10 & 0.72 \\
\hline & 13.21 & 20.00 & & & 0.99 \\
\hline \multirow{3}{*}{ Pushover curve } & 6.63 & $13.74^{a}$ & & & 0.50 \\
\hline & 7.42 & 18.00 & 66068.76 & 151.17 & 0.56 \\
\hline & 8.53 & 28.00 & & & 0.64 \\
\hline
\end{tabular}

a The bi-linear and pushover curve has the same limit displacement value, therefore the approximation of the bi-linear curve has been made correctly. The global ductility demand is defied by $13.74 / 8.66=1.586$, where $8.66 \mathrm{~cm}$ is the displacement defined on the pushover curve that represents the creation of the first plastic hinge;

The slope of the linear curve represents the elastic stiffness of the structure;

Plastic stiffness of the bi-linear curve.

The dynamic instability phenomenon is also affected by the characteristics of the earthquake time-history [13].

Figures 9 and 10 show the demand spectra for damping 5\% and $10 \%$, the linear-elastic capacity curve, bi-linear elastic curve and pushover curve for $\mathrm{K}^{\prime}=\{0.5 \mathrm{~K} ; 1.5 \mathrm{~K}\}$. The base shear is calculated multiplying the total mass of the structure $\left(\mathrm{M}=135.42 \times 10^{3} \mathrm{~kg}\right)$ for the Pseudo-Spectra Accelerations (PSA). Table 4 shows some important results of the analysis regarding some important points of the curves for $\mathrm{K}^{\prime}=0.5 \mathrm{~K}$.

In Table 4, it is possible to compare the linear curve with the pushover curve and to do some observations. If the advantage of the material ductility is ignored, that is if the nonlinear analysis is not carried out, the maximum allowed displacement is $11.60 \mathrm{~cm}$, which is about $16 \%$ less than $13.74 \mathrm{~cm}$. The corresponding base shear is $8.00 \mathrm{MN}$, which is greater than $21 \%$ of $6.63 \mathrm{MN}$.

The first point of the pushover curve is the maximum allowed displacement (elastic plus inelastic) of the structure, which is 13.74 $\mathrm{cm}$. It corresponds to base shear $6.63 \mathrm{MN}$.

It is possible to see also that designing the structure by using linear curve one can obtain a greater shear base of $9.51 \mathrm{MN}$ with the difference of 2.88 MN respect to $6.63 \mathrm{MN}$. By doing so, the structure is over-estimated and could bring financial disadvantages.

For the analysis shown in Figure 10 it is possible to raise the same considerations. Most important values for $\mathrm{K}^{\prime}=1.5 \mathrm{~K}$ are the maximum allowed displacement $12.54 \mathrm{~cm}$ that corresponds to the base shear of $7.27 \mathrm{MN}$ and the global ductility demand 12.54/6.67 = 1.88.

\subsection{Torsional effects - Dynamic Magnification Factor (DMF)}

To consider the torsional effects of the longitudinal seismic stress,

\section{Table 5}

Dynamic Magnification Factor for

$\mathrm{K}^{\prime}=0.5 \mathrm{~K}$ and $\mathrm{K}^{\prime}=1.5 \mathrm{~K}$

\begin{tabular}{|c|c|c|c|}
\hline & & $0.5 \mathrm{~K}$ & $1.5 \mathrm{~K}$ \\
\hline $\begin{array}{c}\text { Dynamic } \\
\text { Magnification Factor }\end{array}$ & DMF & 1.30 & 1.45 \\
\hline Performance point & $d^{*}$ & $13.74 \mathrm{~cm}$ & $12.54 \mathrm{~cm}$ \\
\hline $\begin{array}{c}\text { Amplified } \\
\text { performance point }\end{array}$ & $\mathrm{d}^{*}{ }_{\text {maj }}$ & $17.86 \mathrm{~cm}$ & $18.81 \mathrm{~cm}$ \\
\hline
\end{tabular}

the DMF, which increases the transverse displacement is applied. DMF according to POLB $[5,30]$ is defined by:

$D M F=1,50-0,05 \cdot \frac{L_{L}}{B} \geq 1,10$ for spring stiffness $\mathrm{K}^{\prime}=0.5 \mathrm{~K}$

$D M F=1,65-0,05 \cdot \frac{L_{L}}{B} \geq 1,10$ for spring stiffness $\mathrm{K}^{\prime}=1.5 \mathrm{~K}$

where $L_{L}$ and $B$ are the length and the width of the wharf, respectively. Table 5 shows results of the DMF. In this way, the rotational capacity of the joint must be sufficient for the structure to support a transverse displacement relative to the maximum performance point. Table 6 shows the verification of the rotational capacity of the joint according to Eurocode [6].

Since $\theta_{p, d}>\theta_{p, E}$ the plastic hinge has sufficient rotation capacity to withstand the seismic action.

\section{Conclusion}

In this paper a nonlinear static analysis applied to a pile-supported wharf is carried out. The pile-supported wharf has an area of $6520 \mathrm{~m}^{2}$,

\section{Table 6}

Verification of the rotational capacity of the joint in according to Eurocode [6]

\begin{tabular}{|c|c|c|c|c|c|c|}
\hline \multirow{2}{*}{$\begin{array}{c}\text { Verification of the rotational capacity of the joint } \\
\text { Axial force }\end{array}$} & \multicolumn{3}{|c|}{$0.5 \mathrm{~K}$} & \multicolumn{3}{|c|}{$1.5 \mathrm{~K}$} \\
\hline & $N=$ & -261.5 & $\mathrm{kN}$ & $N=$ & -291.0 & $\mathrm{kN}$ \\
\hline Curvature of the idealized M-C diagram & $\phi_{y, \text { ideal }}=$ & 0.00459 & $1 / \mathrm{m}$ & $\phi_{\text {y.ideal }}=$ & 0.00461 & $1 / \mathrm{m}$ \\
\hline $\begin{array}{l}\text { Distance of the pile/superstructure intersection } \\
\text { up to zero bending moment in the pile }\end{array}$ & $L=$ & 4 & $\mathrm{~m}$ & $L=$ & 4 & $\mathrm{~m}$ \\
\hline Plastic hinges length & $L_{p}=$ & 0.87 & $\mathrm{~m}$ & $L_{p}=$ & 0.87 & $\mathrm{~m}$ \\
\hline Ultimate curvature in the idealized M-C diagram & $\phi_{\mathrm{u}}=$ & 0.05200 & $1 / \mathrm{m}$ & $\phi_{\mathrm{u}}=$ & 0.05210 & $1 / \mathrm{m}$ \\
\hline Ultimate capacity of the plastic rotation & $\theta_{p, u}=$ & 0.03676 & rad & $\theta_{p, u}=$ & 0.03682 & rad \\
\hline Security factor & $\gamma_{R, p}=$ & 1.4 & - & $\gamma_{R, p}=$ & 1.4 & - \\
\hline Capacity of the design plastic rotation & $\theta_{p, d}=$ & 0.02626 & $\mathrm{rad}$ & $\theta_{p, d}=$ & 0.0263 & rad \\
\hline Plastic rotation in the target displacement & $\theta_{\mathrm{p}, \mathrm{E}}=$ & 0.0086 & $\mathrm{rad}$ & $\theta_{\mathrm{p}, \mathrm{E}}=$ & 0.0116 & rad \\
\hline
\end{tabular}


the length in the transversal direction is $40.0 \mathrm{~m}$ and the length in the longitudinal direction is $163.0 \mathrm{~m}$.

The seismic activity in this area where the port is placed is very intense, with a value of $0.55 \mathrm{~g}$ PGA. For periods greater than 0.64 $\mathrm{s}$, the code Covenin is higher than the Eurocode, which means that the code Covenin is more conservative in respect to Eurocode.

Geotechnical characteristics have been studied and the areas have been divided in three principal parts: valley-area, hill-area and sea-area. The latter has marine sediments of more compressible silt-clay with a thickness of $10.00 \mathrm{~m}$ and conglomerates "coche"-formation.

The NSP using CSM has been explained step-by-step as follows: the seismic demand, capacity of the structure, conversion to ADRS, selecting displacement, bi-linear curve, reduction of seismic demand and convergence. The procedure is consistent to the literature [3].

The 3D analysis of the pile-supported wharf is useful to calculate the vibration modes, the loads and the interaction fluid-structuresoil. In this analysis, the MPMR for the second mode in $\mathrm{x}$ direction is predominant $(99.77 \%)$, therefore the choice of the direction of the pushover analysis is the $x$ direction.

In the modelling, the nonlinear behaviour of the material is fundamental; 44 plastic hinges in accordance to literature [4] have been assigned and the constitutive equations refer to the Mander's model [8].

Since the structure has strategic importance, it is important to analyse the consequences of the structure failure and to estimate maximum allowed displacement. The most severe wharf damage corresponds to failure of piles along an extended length of the wharf structure.

The final results have been shown in the graphic base shear vs. displacement. The base shear is calculated by multiplying the total mass by the PSA. The allowed displacement is $18.81 \mathrm{~cm}$.

It is interesting to note that, for the elastic curve, the allowed displacement is up to $7.2 \mathrm{~cm}$ less than the inelastic curve's displacement. This difference represents the advantage of the material ductility. With the pushover analysis it is possible "to push over" the structure.

If in the pushover analysis the continuous change of the dynamic parameters is considered, the result of the pushover analysis is very close to the results of the dynamic analysis.

\section{Acknowledgements}

Authors acknowledge the EGT Engenharia Ltda Brazilian company for the materials used in the development of the present research. The first author acknowledges the University of Salamanca to pay the rights (when applicable) to completely download all papers in the references.

\section{Funding}

This work has been carried out thanks to the partnership between University of Roma Tre in Italy, Polytechnic School of São Paulo in Brazil and EGT Engenharia Ltda Brazilian company. This study was funded by EGT Engenharia Ltda Brazilian company [reference number: 00.376.282/0001-26].

\section{References}

[1] Freeman, S.A. Review of the development of the capacity spectrum method. ISET Journal of Earthquake Technology, v.41, n.438, 2004, pp.1-13.

[2] Permanent International Association for Navigation Congresses (PIANC). Seismic Design Guidelines for Port Structures. Working group n.34 of the Maritime Navigation Commission, International Navigation Association, $1^{\mathrm{a}}$ ed., 2001, A.A. Balkema Publishers, 474 p.

[3] Applied Technology Council (ATC-40). Seismic Evaluation and Retrofit of Concrete Buildings. California Seismic Safety Commission, Redwood City, California, v.1, report n.SSC 96-01, 1996.

[4] California Department of Transportation (CALTRANS). Seismic Design Criteria (SDC). Version 1.6, Sacramento, California, 2010.

[5] Port of Long Beach (POLB). Wharf Design Criteria. Version 2.0, 2009.

[6] European Committee for Standardization (CEN). Eurocode 8: Design of Structures for Earthquake Resistance - Part 1: General Rules, Seismic Actions and Rules for Buildings, EN 1998-1:2004.

[7] Fundación Venezolana de Investigaciones Sismológicas Covenin 1756-1:2001, Funvisis. Edificaciones Sismorresistentes, Parte 1: Requisitos, Fondonorma, Caracas, 2001.

[8] Mander, J.B., Priestley, M.J.N., Park, R. Theoretical stressstrain model for confined concrete. Journal of Structural Engineering, v.114, n.8, 1988, pp.1804-1825.

[9] Kramer, S. L. Geotechnical Earthquake Engineering. Prentice-Hall, Upper Saddle River, New Jersey, 1ed., 1996, $653 \mathrm{p}$.

[10] Freeman, S.A. Response spectra as a useful design and analysis tool for practicing structural engineers. ISET Journal of Earthquake Technology, v.44, n.475, 2007, pp.25-37.

[11] Chopra, A.K., Goel, R.K. A modal pushover analysis procedure to estimate seismic demands for unsymmetric-plan buildings. Earthquake Engineering and Structural Dynamics, v.33, 2004, pp.903-927.

[12] Elnashai, A.S. Advanced inelastic static (pushover) analysis for earthquake applications. Structural Engineering and Mechanics, v.12, n.1, 2001, pp.51-69.

[13] Aydinoglu, M.N. Incremental response spectrum analysis (IRSA) procedure for multi-mode pushover including p-delta effects. In: $13^{\text {th }}$ World Conference on Earthquake Engineering, paper n.1440, Vancouver, B.C., Canada, August 1-6, 2004.

[14] Nozu, A., Ichii, K., Sugano, T. Seismic design of port structures. Journal of Japan Association for Earthquake Engineering, v.4, n.3, 2004, pp.195-208.

[15] American Society of Civil Engineers (ASCE). Seismic Design of Piers and Wharves. ASCE/COPRI 61-14, 2014, 90 p.

[16] Sap2000. Version 16.0.0 Plus. Computers and Structures, Inc, California/New York, 2013.

[17] Alembagheri, M. Earthquake damage estimation of concrete gravity dams using linear analysis and empirical failure criteria. Soil Dynamics and Earthquake Engineering, v.90, 2016, pp.327-339. 
[18] Takahashi, A., Takemura, J. Liquefaction-induced large displacement of pile-supported wharf. Soil Dynamics and Earthquake Engineering, v.25, 2005, pp.811-825.

[19] Ning, N., Yu, D., Zhang, C., Jiang, S. Pushover analysis on infill effects on the failure pattern of reinforced concrete frames. Applied Sciences, v.7 2017, pp.428-442.

[20] Consenza, E., Manfredi, G., Verderame, G.M. A fibre model for push-over analysis of underdesigned reinforced concrete frames. Computers and Structures, v.84, 2006, pp.904-916.

[21] Hasan, R., Xu, L., Grierson, D.E. Push-over analysis for performance-based seismic design. Computers and Structures, v.88, 2002, pp.2483-2493.

[22] Shayanfar, M.A., Rakhshanimehr, M., Zare Bidoki, R. An energy based adaptive pushover analysis for nonlinear static procedures. Civil Engineering Infrastructures Journal, v.49, 2016, pp.289-310.

[23] Shafieezadeh, A., Des Roches, R., Rix, G.J., Werner, S.D. A probabilistic framework for correlated seismic downtime and repair cost estimation of geo-structures. Engineering Earthquake and Structural Dynamics, v.2013, 2013, pp.1-17.

[24] Cao, S., Yuan, W. Modified generalized pushover analysis for estimating longitudinal seismic demands of bridges with elevated pile foundation systems. Latin American Journal of Solids and Structures, v.11, 2014, pp.2696-2712.

[25] Riyad, Y., kiss, B., Mrani, I., Parron, M.A., Dolores, R.C.M. Seismic retrofitting: reinforced concrete shear wall versus CFRP reinforced concrete using pushover analysis. Journal of Materials and Engineering Structures, v.3, 2016, pp.181-195.

[26] Ghanoonibagha, M., Gol, M.R.A., Ranjbar, M.R. Study of higher mode effects and lateral load patterns in pushover analysis of steel frames with steel shear wall. Advances in Science and Technology Research Journal, v.10, 2016, pp.13-27.

[27] Mortezaei, A., Ronagh, H.R. Effectiveness of modified pushover analysis procedure for the estimation of seismic demands of buildings subjected to near-fault ground motions having fling step. Natural Hazards and Earth System Sciences, v.13, 2013, pp.1579-1593.

[28] Hedayat, A.A., Yalciner, H. Assessment of an existing RC building before and after strengthening using nonlinear static procedure and incremental dynamic analysis. Shock and Vibration, v.17, 2010, pp.619-629.

[29] AutoCAD. Version 2010, Autodesk, Inc., 2010.

[30] Port of Long Beach (POLB). Wharf Design Criteria. Version 4.0, 2015. 